\title{
Study on Compressive Strength of Quarry Dust as Fine Aggregate in Concrete
}

\author{
K. Shyam Prakash ${ }^{1}$ and Ch. Hanumantha $\operatorname{Rao}^{2}$ \\ ${ }^{1}$ Department of Civil Engineering, PVP Siddhartha Institute of Technology, Kanuru, Vijayawada, Andhra Pradesh 520007, India \\ ${ }^{2}$ Department of Civil Engineering, K L University, Vijayawada 520001, India \\ Correspondence should be addressed to K. Shyam Prakash; shyamprakashcivil@gmail.com
}

Received 10 April 2016; Revised 27 May 2016; Accepted 30 June 2016

Academic Editor: Cumaraswamy Vipulanandan

Copyright ( 2016 K. Shyam Prakash and Ch. H. Rao. This is an open access article distributed under the Creative Commons Attribution License, which permits unrestricted use, distribution, and reproduction in any medium, provided the original work is properly cited.

\begin{abstract}
The concept of replacement of natural fine aggregate by quarry dust which is highlighted in the study could boost the consumption of quarry dust generated from quarries. By replacement of quarry dust, the requirement of land fill area can be reduced and can also solve the problem of natural sand scarcity. The availability of sand at low cost as a fine aggregate in concrete is not suitable and that is the reason to search for an alternative material. Quarry dust satisfies the reason behind the alternative material as a substitute for sand at very low cost. It even causes burden to dump the crusher dust at one place which causes environmental pollution. From the results of experimental investigations conducted, it is concluded that the quarry dust can be used as a replacement for fine aggregate. It is found that $40 \%$ replacement of fine aggregate by quarry dust gives maximum result in strength than normal concrete and then decreases from $50 \%$. The compressive strength is quantified for varying percentage and grades of concrete by replacement of sand with quarry dust.
\end{abstract}

\section{Introduction}

Quarry dust is a byproduct of the crushing process which is a concentrated material to use as aggregates for concreting purpose, especially as fine aggregates. In quarrying activities, the rock has been crushed into various sizes; during the process the dust generated is called quarry dust and it is formed as waste. So it becomes as a useless material and also results in air pollution. Therefore, quarry dust should be used in construction works, which will reduce the cost of construction and the construction material would be saved and the natural resources can be used properly. Most of the developing countries are under pressure to replace fine aggregate in concrete by an alternate material also to some extent or totally without compromising the quality of concrete. Quarry dust has been used for different activities in the construction industry, such as building materials, road development materials, aggregates, bricks, and tiles.

The present research work mainly deals with the influence of different replacement proportion of sand with quarry dust on the properties of concrete. The present study is planned to study the effects of quarry dust addition in normal concrete and to assess the rate of compressive strength development.

\section{Literature Review}

The suitability of quarry dust as a sand replacement material shows that the mechanical properties are improved and also elastic modulus. The compressive strength achieved optimum by replacing fine aggregate with quarry dust in ratio of $60: 40$ as done by Hmaid Mir [1].

Felekoglu et al. [2] observed that the incorporation of quarry waste at the same cement content generally reduced the super plasticizer requirement and improved the 28 days' compressive strength of SCC. Normal strength SCC mixtures that contain approximately $300-310 \mathrm{Kg}$ of cement per cubic meter can be successfully prepared by employing high amount of quarry waste. Sukumar et al. [3] found that the relations have been established for the increase in compressive strength at premature ages of curing ( $12 \mathrm{~h}$ to 28 days) for different grades of SCC mixes and are compared 
with the IS Code formula for straight concrete as per IS: SP 231982. Ho et al. [4] explained that the granite fines can be used in the SCC production. However, it is important to spot out that, as a waste material, the properties of stone fines are likely to vary with time. Then, after that, the fineness of granite fines could solve durability problems, such as silica-alkali reactions. These two issues would require to be addressed if the material is to be used with assurance.

Utilization of quarry dust in concrete is recommended particularly in regions where sand is not easily available (Dehwah [5]).

Muhit et al. [6] determined that passing from $200 \mathrm{~mm}$ sieve is used as cement replacement whereas retaining from $100 \mathrm{~mm}$ sieve is used as sand replacement. Cement was replaced with stone dust in percentage of 3,5 , and 7 percent. Similarly, sand was replaced with stone dust in percentage of 15 to 50 with an increase of 5 percent. Test result gives that compressive strength of mould with $35 \%$ of sand and $3 \%$ of cement replacing dust increases to $21.33 \%$ and $22.76 \%$ in that order compared to the normal mortar mould at 7 and 28 days for tensile strength which increased to $13.47 \%$.

Ukpata and Ephraim [7] identified the flexural and tensile strength properties compared with those for normal concrete. Hence, concrete proportion of lateritic sand and quarry dust can be used for construction provided the mixture of lateritic sand content is reserved below 50\%. Both flexural strength and tensile strength are increased with increase in lateritic content.

According to Soutsos et al. [8], the physical characteristics of recycled destruction aggregates may unfavorably affect the properties of the blocks. However, levels of replacement of quarried stone aggregates with destruction recycled aggregates determined that it will not have significant harmful effect on the compressive strength.

It is observed that there is consistent increase in the strength of plain concrete when natural sand is fully replaced by quarry dust (Chitlange and Pajgade [9]).

Concrete containing quarry dust as fine aggregate can be effectively utilized in the construction industry with good quality materials, appropriate dosage of super plasticizer, appropriate mixing methods, and proper curing thereby ensuring sustainable development against environmental pollution (Devi and Kannan [10]).

The investigation proposes that the stone dust can be replaced up to $50 \%$ without any effect on mechanical and physical properties and the economical saving will be $56 \%$ also as discussed by Nanda et al. [11].

The study of Ilangovana et al. [12] gives attention to physical and chemical properties of quarry dust with respect to requirements of codal provision which are satisfied. The $100 \%$ replacement of sand with quarry dust gives better results in terms of compressive strength studies.

\section{Tests on Quarry Dust}

Quarry dust is a result of crushers while doing quarrying activities. Quarry dust was obtained from nearby quarries at the home places like Paritala region, Kanchikacherla mandal,
Vijayawada (rural). The present investigations are aimed at studying the effect of quarry dust when it is replaced with sand partially in concrete. The quarry dust samples collected from Paritala region were studied and compared in terms of geotechnical properties. The physical properties of Zone II following quarry dust were used in compressive strength study. The program involves casting and testing cube specimens in each set consisting of 3 cubes. The variation in standard deviation of strength greater than $10 \mathrm{~N} / \mathrm{mm}^{2}$ is not considered for every set of the whole series. The cubes were casted using standard cubes of $150 \mathrm{~mm} \times 150 \mathrm{~mm} \times 150 \mathrm{~mm}$. Specific gravity of sand and quarry dust of 2.62 and 2.70 for Zone II classified type is obtained. 53 grade cement is used for the mix. Curing was done by conventional moist curing for the concrete mix. Compression testing machine of $2000 \mathrm{KN}$ capacity was used to test the cubes' specimens. The set of series is as follows:

(a) In the first series, M30 grade of concrete with 20, 25, and 30 percentage replacement of quarry dust tested for 3 days, 7 days, 28 days, and 60 days is studied and the results are presented.

(b) In the second series, M25 grade of concrete with 20, 25 , and 30 percentage replacement of quarry dust tested for 3 days, 7 days, and 28 days is studied and the results are presented.

(c) In the third series, M20, M25, and M30 grades of concrete with 20,25, and 30 percent replacement of quarry dust by varying the water-cement ratio of 0.45 and 0.50 are studied and the results are presented.

(d) In the fourth series, M20, M30, and M40 grades of concrete with 20,30, and 40 percent replacement of quarry dust with water-cement ratio of 0.45 are studied and the results are presented.

(e) In the fifth series, M20 grade of concrete with 10 percent increment up to 100 percent replacement of quarry dust is studied and the results are presented.

\section{Discussion on Results}

(a) The compressive strength results of quarry dust concrete (cubes) were obtained in the first series, where M30 grade of concrete with 20,25, and 30 percent replacement of quarry dust tested for 3 days, 7 days, 28 days, and 60 days is studied and the results are presented. The specimens were casted with conventional materials; that is, fine aggregate is natural river sand with M30 grade by using ordinary Portland cement (OPC).

With the increase in age of concrete, the compressive strength increases up to 30 percent replacement of quarry dust as a fine aggregate. The partial replacement of quarry dust gave a 60 days' peak compressive strength at $30 \%$ replacement level. Figure 1 shows the compressive strength of M20 grade with varying age of concrete by replacement level up to $30 \%$.

(b) The compressive strength results of quarry dust concrete (cubes) were obtained in the second series, where M25 grade of concrete with 20,25, and 30 percent replacement of 


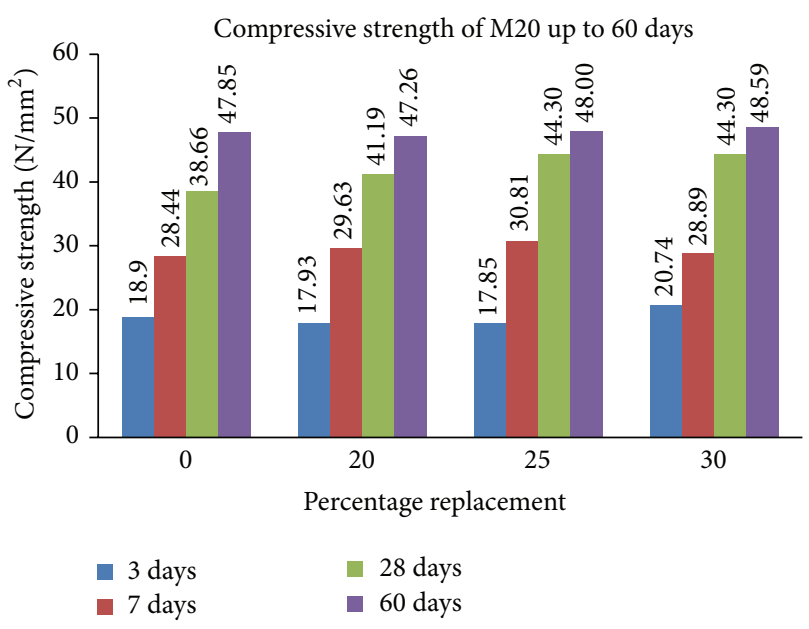

FIGURE 1: Compressive strength of M20 grade with change in age.

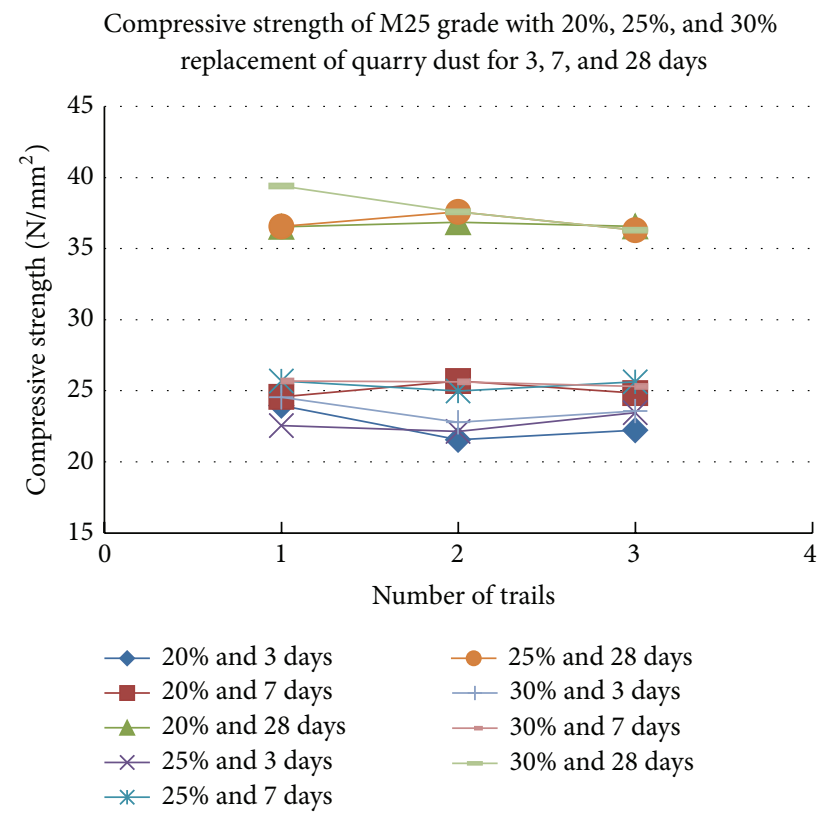

Figure 2: Compressive strength of M25 with 20\%, 25\%, and 30\% replacement for 3,7 , and 28 days.

quarry dust tested for 3 days, 7 days, and 28 days is studied and the results are presented.

With observation of $20 \%$ of quarry dust ( 7 days), the average compressive strength is $29.62 \mathrm{~N} / \mathrm{mm}^{2}$ whereas that for natural sand is $28.44 \mathrm{~N} / \mathrm{mm}^{2}$. For $25 \%$ quarry dust, the value increased to $30.81 \mathrm{~N} / \mathrm{mm}^{2}$. Finally, for $30 \%$ quarry dust, the strength increased to $32.88 \mathrm{~N} / \mathrm{mm}^{2}$. Hence, quarry dust can be effectively used to replace natural sand, without reduction in the strength of concrete. The slight variation is observed in compressive strength for 3 days' and 7 days' age in concrete. As the age of the concrete increases, the compressive strength up to 30 percent replacement of quarry dust also increases. The partial replacement of quarry dust gave a 28 days' peak compressive strength at $30 \%$ replacement level. Figure 2 shows that the compressive strength of M25

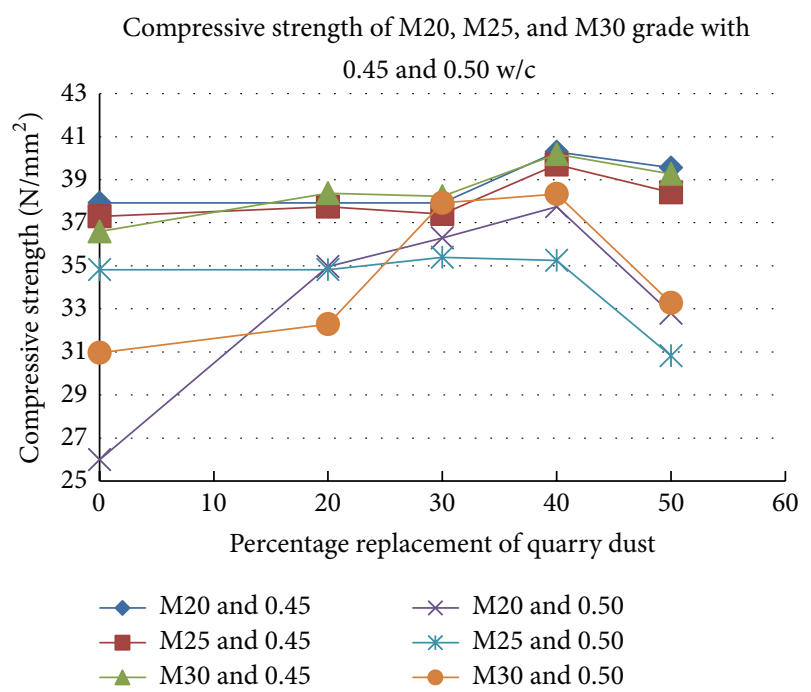

FIGURE 3: Compressive strength of M20, M25, and M30 grade with w/c 0.45 and 0.50 .

grade also was observed with varying age of concrete by replacement level up to $30 \%$.

(c) The compressive strength results of quarry dust concrete (cubes) were obtained in the third series, where M20, M25, and M30 grades of concrete with 20, 25, and 30 percent replacement of quarry dust and also workability are studied by varying the water-cement ratio of 0.45 and 0.50 and the results are presented.

When $40 \%$ sand is replaced with quarry dust, there is a variation of $10 \%$ to $15 \%$ increment in compressive strength for $0.45 \mathrm{w} / \mathrm{c}$ and $0.50 \mathrm{w} / \mathrm{c}$. The partial replacement of quarry dust gave a 28 days' peak compressive strength at $40 \%$ replacement level and decreases for $50 \%$ replacement. Figure 3 shows the compressive strength relation for both normal concrete and quarry dust concrete, at the age of 28 days for M30, M25, and M20 grades of concrete for different $\mathrm{w} / \mathrm{c}$ ratios of 0.45 and 0.5 .

For M20 grade and w/c 0.5, conventional concrete workability is found to be 0.95 . For $20 \%$ quarry dust workability is 0.94 . Further workability is decreased to 0.93 for $30 \%$ replaced concrete. For $40 \%$ quarry dust concrete workability is 0.90 and for $50 \%$ replacement of quarry dust concrete 0.89 compacting factor was observed.

For M25 grade and w/c 0.5, conventional concrete workability is found to be 0.98 . For $20 \%$ quarry dust workability is 0.98 . Further workability is decreased to 0.97 for $30 \%$ replaced concrete. For $40 \%$ quarry dust concrete workability is 0.97 and for $50 \%$ replacement of quarry dust concrete 0.96 compacting factor was observed.

For M30 grade and w/c 0.5, conventional concrete workability is found to be 0.97 . For $20 \%$ quarry dust workability is 0.94 . Further workability is decreased to 0.93 for $30 \%$ replaced concrete. For $40 \%$ quarry dust concrete workability is 0.93 and for $50 \%$ replacement of quarry dust concrete 0.87 compacting factor was observed.

(d) The compressive strength results of quarry dust concrete (cubes) were obtained in the fourth series, where M20, M30, and M40 grades of concrete with 20, 30, and 40 


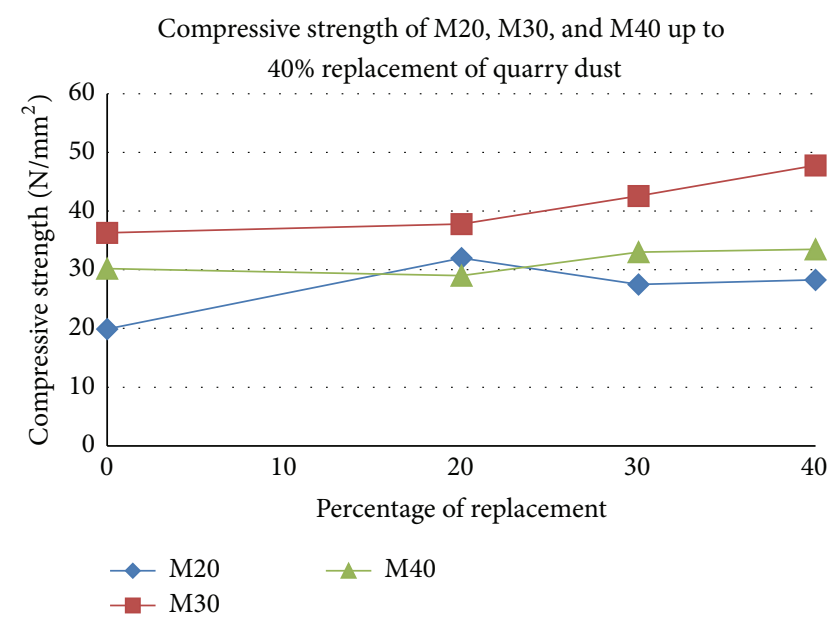

Figure 4: Compressive strength of M20, M30, and M40 grade up to $40 \%$ replacement of quarry dust.

percent replacement of quarry dust with water-cement ration of 0.45 are concentrated and the results are presented.

The observations also concentrated on variation of grades of concrete by replacement of quarry dust. The change in grades up to 40 percent replacement increases the compressive strength. Figure 4 shows the compressive strength of varying grade and age of concrete by replacement level up to $40 \%$. The compressive strength of M30 grade possesses better results than the M40 grade concrete. The observation here in this graph regarding the compressive strength up to $40 \%$ is the increases for the grade changes as M20, M30, and M40.

(e) The compressive strength results of quarry dust concrete (cubes) were obtained in the fifth series, where M20 grade of concrete with 10 percent increment up to 100 percent replacement of quarry dust is concentrated and the results are presented.

The study aimed to observe the compressive strength properties of quarry dust by varying full percentage replacement. The results show increase in strength up to 40 percent level and then an onwards decrease in compressive strength with change in age for M20 grade of concrete. Figure 5 shows the compressive strength of varying age of concrete by 100 percent replacement of quarry dust.

\section{Conclusions}

The concept of replacement of natural fine aggregate by quarry dust highlighted in the present investigation could improve the utilization of generated quarry dust, thus reducing the requirement of land fill area and conserving the scarcely available natural sand sustainable development. Strength of the concrete is mainly dependent on bonding of the fine aggregates which fills the voids between the coarse aggregates.

It is found that the strength of concrete is more for w/c of 0.45 when compared with w/c of 0.5 . As the quantity of water increases, the compressive strength decreases when replaced with quarry dust. This is due to the water absorption property of quarry dust. It is well known that the w/c ratio increases

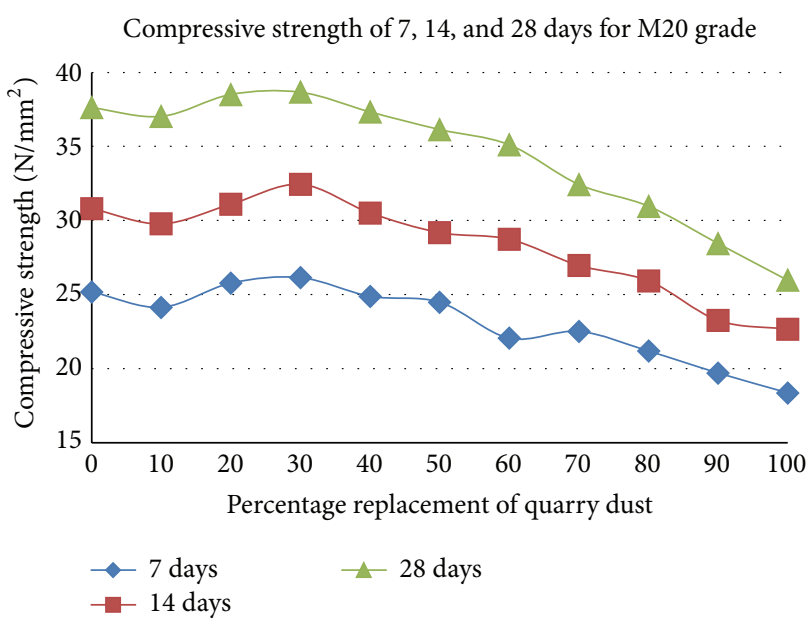

FIGURE 5: Compressive strength of 7, 14, and 28 days for M20 grade up to $100 \%$ replacement of quarry dust.

as the strength decreases. But the observation regarding compressive strength of quarry dust when compared to sand is nonlinear.

From the experimental study, it is concluded that the quarry dust can be used as a replacement for fine aggregate. It is found that $40 \%$ replacement of sand by quarry dust gives maximum result in strength compared to normal concrete and then decreases from 50\%. The results proved that up to $40 \%$ replacement of sand by the quarry dust induced higher compressive strength and the workability of concrete decreases as replacement increases. Thus the environmental effects and waste can be significantly reduced.

\section{Competing Interests}

The authors declare that they have no competing interests.

\section{References}

[1] A. Hmaid Mir, "Improved concrete properties using quarry dust as replacement for natural sand," International Journal of Engineering Research and Development, vol. 11, no. 3, pp. 46-52, 2015.

[2] B. Felekoglu, K. Tosun, B. Baradan, A. Altun, and B. Uyulgan, "The effect of fly ash and limestone fillers on the viscosity and compressive strength of self-compacting repair mortars," Cement and Concrete Research, vol. 36, no. 9, pp. 1719-1726, 2006.

[3] B. Sukumar, K. Nagamani, and R. Srinivasa Raghavan, "Evaluation of strength at early ages of self-compacting concrete with high volume fly ash," Construction and Building Materials, vol. 22, no. 7, pp. 1394-1401, 2008.

[4] D. W. S. Ho, A. M. M. Sheinn, C. C. Ng, and C. T. Tam, “The use of quarry dust for SCC applications," Cement and Concrete Research, vol. 32, no. 4, pp. 505-511, 2002.

[5] H. A. F. Dehwah, "Corrosion resistance of self-compacting concrete incorporating quarry dust powder, silica fume and fly ash," Construction and Building Materials, vol. 37, pp. 277-282, 2012. 
[6] I. B. Muhit, M. T. Raihan, and M. Nuruzzaman, "Determination of mortar strength using stone dust as a partially replaced material for cement and sand," Advances in Concrete Construction, vol. 2, no. 4, pp. 249-259, 2014.

[7] J. O. Ukpata and M. E. Ephraim, "Flexural and tensile strength properties of concrete using lateristic sand and quarry dust," ARPN Journal of Engineering and Applied Sciences, vol. 7, pp. 324-331, 2012.

[8] M. N. Soutsos, K. Tang, and S. G. Millard, "Concrete building blocks made with recycled demolition aggregate," Construction and Building Materials, vol. 25, no. 2, pp. 726-735, 2011.

[9] M. R. Chitlange and P. S. Pajgade, "Strength appraisal of artificial sand as fine aggregate in SFRC," ARPN Journal of Engineering and Applied Sciences, vol. 5, no. 10, pp. 34-38, 2010.

[10] M. Devi and K. Kannan, "Analysis of strength and corrosion resistance behavior of inhibitors in concrete containing quarry dust as fine aggregate," Journal of Engineering and Applied Sciences, vol. 6, no. 11, pp. 124-135, 2011.

[11] R. P. Nanda, A. K. Das, and N. Moharana, "Stone crusher dust as a fine aggregate in concrete for paving blocks," International Journal of Civil and Structural Engineering, vol. 1, no. 3, p. 613, 2010.

[12] R. Ilangovana, N. Mahendrana, and K. Nagamanib, "Strength and durability properties of concrete containing quarry rock dust as fine aggregate," ARPN Journal of Engineering and Applied Sciences, vol. 3, no. 5, pp. 20-26, 2008. 


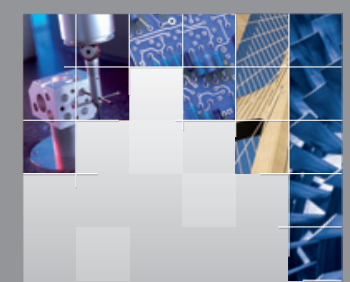

\section{Enfincering}
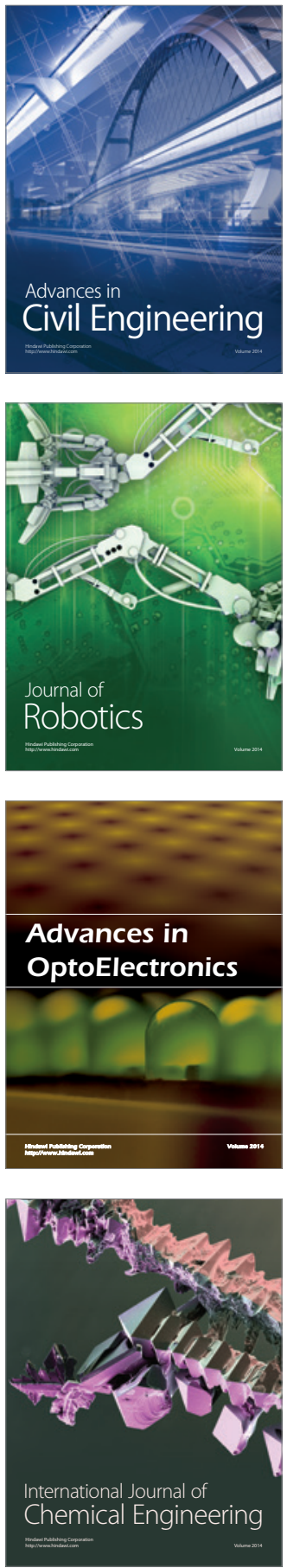

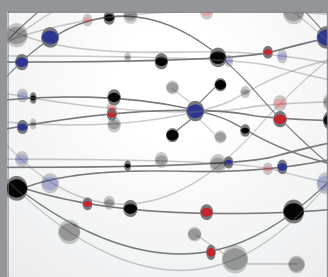

The Scientific World Journal

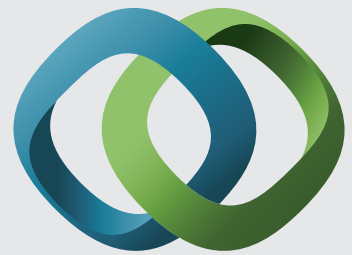

\section{Hindawi}

Submit your manuscripts at

http://www.hindawi.com
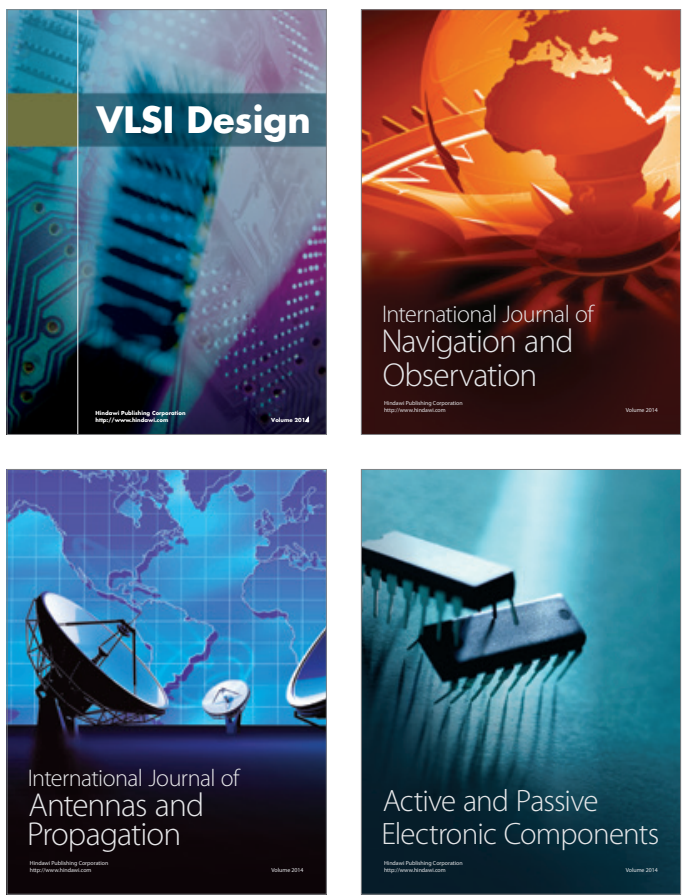
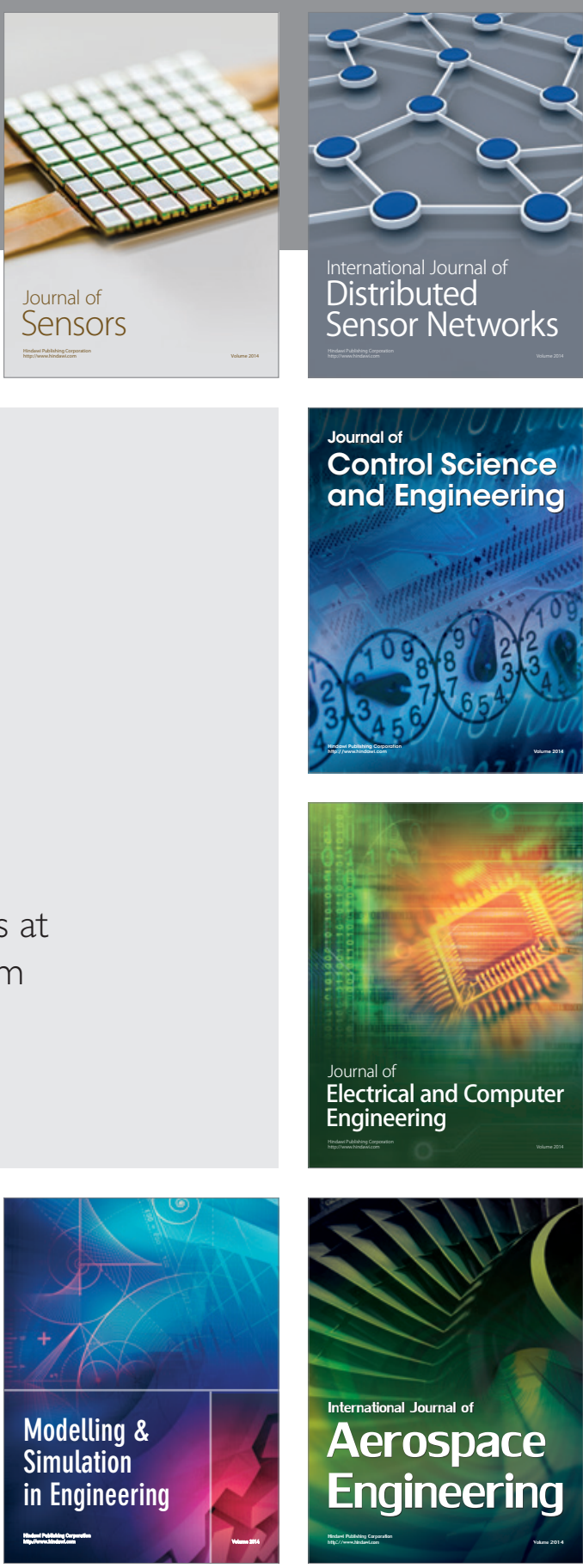

International Journal of

Distributed

Sensor Networks

Journal of

Control Science

and Engineering
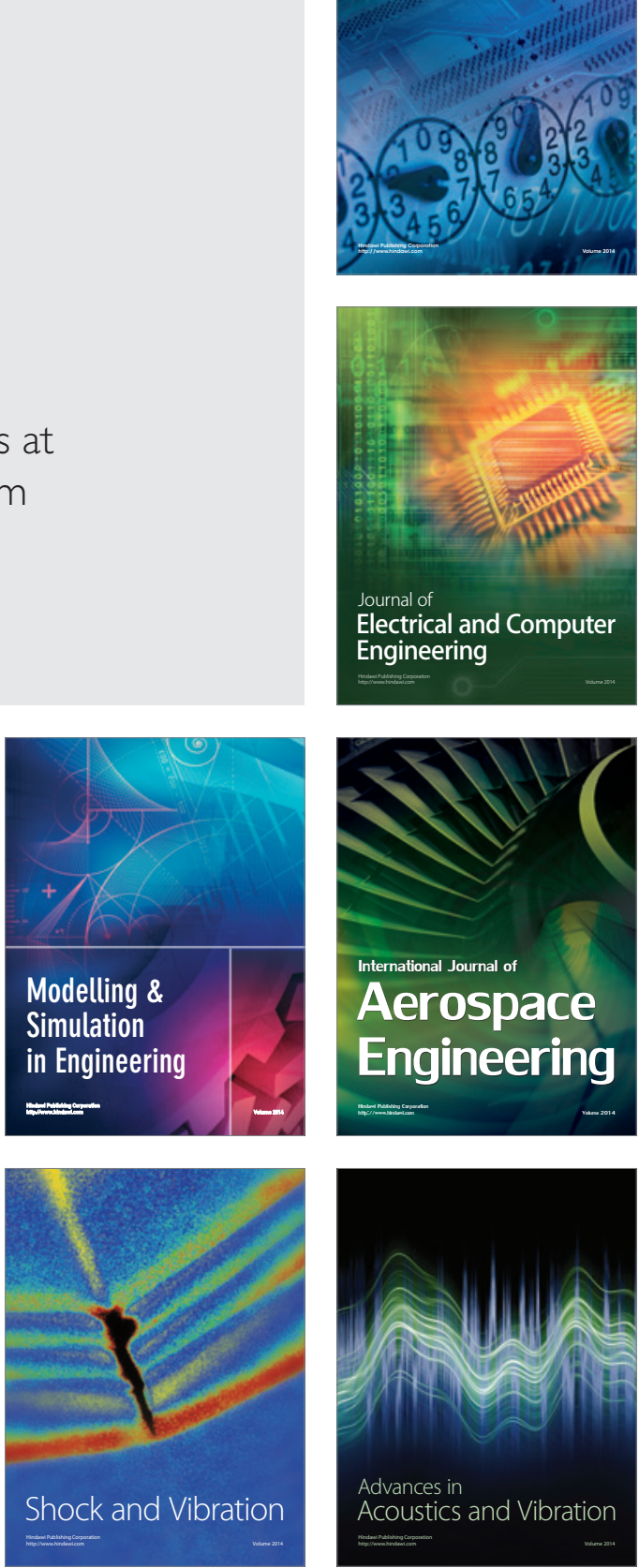